\title{
The integration of social science information into Great Lakes fishery management: Opportunities and challenges
}

Nadine Heck ${ }^{a, *}$, Richard C. Stedman ${ }^{a}$, Marc Gaden ${ }^{b}$

${ }^{a}$ Department of Natural Resources, Cornell University, Ithaca, NY, USA

${ }^{b}$ Great Lakes Fishery Commission, Ann Arbor, MI, USA

* Corresponding author. Tel.: +1 6073795982. E-mail address: tnm heck@yahoo.de (N. Heck).

\section{Abstract}

Fishery management is increasingly moving toward management that accounts for

environmental and social dimensions. Such an approach requires the integration of natural and social science information into planning and decision-making processes. The actual integration of social science information, however, remains limited in many policy and decision-making processes within fisheries. Our study provides insights into factors that influence the intention to use social science information among fishery managers and the actual integration of such information into fishery management. Based on interviews with fishery managers in the Great Lakes, we find that the lack of social science expertise in fishery management agencies leads to multiple negative beliefs and attitudes, and subsequently a low intention to use social science information in decision-making processes. At the same time, the paper finds that more expertise in decision-making tools and basing social science on equal footing with natural sciences within fishery management institutions appears critical to advance the actual integration of social science information in fishery management.

This is the accepted manuscript of a paper published in Fisheries Research. The final version is accessible at https://doi.org/10.1016/i.fishres.2015.01.008.

\section{Introduction}

Fisheries worldwide are increasingly managed as social-ecological systems that aim to achieve environmental and socio-economic goals (Hunt et al., 2013). Fishery managers thus need to account not only for biological and ecological considerations of fisheries, but also economic and social ones and the role of governance models to achieve desired goals (Möllmann et al., 2013; Urquhart et al., 2011). Such a management approach requires the integration of information across the natural and social science divide in management and decision-making process of fisheries (Hunt et al., 2013; Coll et al., 2013; Haapasaari et al., 2012). In addition, fisheries management is not only affected by the inherent unpredictability of the resource itself but also by social, economic, and regulatory uncertainties that affect the use of fish resources (Mahon et al., 2008). Social science information is thus critical to improve adaptive capacity of fishery management in order to address these uncertainties (Arlinghaus et al., 2013; Arlinghaus, 2006). 
The integration of social science and bio-ecological data in policy and decision-making processes within management agencies, however, remains limited (Evely et al., 2008). Fishery managers are typically trained in natural sciences. Subsequently, decisionmaking processes are often based primarily on ecological and biological information (Bunnefeld et al., 2011). Neglecting social dimensions in decision-making processes, however, can be a critical mistake. The success or failure of natural resource management is often determined at least as much by social and institutional factors as ecological ones, especially given that fishery management programs in general aim to manage human behavior (Mascia, 2003; Fulton et al., 2011; Decker et al., 2001). If policies and programs are based on unsubstantiated assumptions about participants and their motivations, in this case fishermen, they are likely to fail (Ostrom, 1999).

The integration of social and ecological science information in the management of complex systems can be challenging due to potential communication differences or disciplinary silos (Heberlein, 1988; Eigenbrode et al., 2007). Combining natural and social science information, for example, typically requires the willingness to work across disciplines and engage with different underlying epistemologies and methods (Fazey et al., 2006; Evely et al., 2008) that might be unfamiliar to fishery managers and decision makers trained in ecology and biology.

Another important point is the recognition of the diversity of social science disciplines. Social sciences, as natural sciences, is an umbrella term that contains a range of sub-disciplines. Examples of social science disciplines that are of interest in fishery management include economics, anthropology, political science, sociology, psychology, human geography, history, or ethics (Symes and Hoefnagel, 2010; Decker et al., 2001). All of these disciplines provide different insights into fishery relevant topics. Disciplines like economics and psychology often rely on quantitative data collection and analysis approaches. Disciplines such as history, ethics, or political sciences might rely more on qualitative data while human geography can provide spatial insights. Despite this diversity of social science disciplines, social sciences are often equated with qualitative approaches that are perceived as less rigorous than quantitative ones (Lele and Norgaard, 2005). Qualitative approaches, however, can be as rigorous as quantitative ones even though they are at times not perceived as "science" (Lele and Norgaard, 2005). It might be necessary to educate practitioners who are familiar with natural science information such as fishery managers about the diversity of social science disciplines, their underlying approaches (qualitative and quantitative); the rigor and value of qualitative approaches that might be unfamiliar to them. Otherwise, fishery managers might dismiss such data and not integrate it into decision-making processes. Perceptions unfortunately do not change easily and methodological approaches that lie outside of well know disciplines are likely viewed with discomfort, if not outright suspicion (Holling, 1998).

\subsection{The Great Lakes fishery}

Our study investigates factors that influence the integration of social science information into fishery management in the Great Lakes. The Great Lakes basin consists of five connected lakes (Superior, Huron, Michigan, Erie, and Ontario) that make up the largest surface freshwater system in the world (EPA 2014) (Fig. 1). 
The Great Lakes fishery includes commercial, recreational, and tribal fisheries (Gaden et al., 2012). Recreation fishing is dominant in the seven US states in the basin; commercial fishing is the main fishery in Ontario. The management of the fishery across the basin is shared among federal, state, and provincial government agencies, and tribal authorities/First Nations in the US and Canada (Gaden et al., 2012) (Fig. 2).

Contemporary ecological and social changes in the basin that potentially affect Great Lakes fishery include climate change (Cline et al., 2013, 2014), the spread of pathogens and aquatic invasive species by diverse human activities (Bain et al., 2010; Kilian et al., 2012; Kelly et al., 2013), and demographic changes associated with migration and economic patterns (Breffle et al., 2013). Based on the complexity of these social and ecological issues, there is a need to understand human-environment interaction of the Great Lakes fishery. Subsequently, information from both natural and social science should inform decision-making processes to account for ecological and social dimensions that underlie fishery management (Decker et al., 2012). Previous academic studies provide some insights to these issues (e.g. Connelly et al., 1999; Bishop et al., 1987; Connelly and Brown, 2010; Bishop et al., 1990; Milliman et al., 1992; Pejchar and Mooney, 2009; Rothlisberger et al., 2010; Roy et al., 2010). The integration of social science information into management and decision-making, however, seems limited or absent so far. Our study investigates this point by looking at factors that challenge and facilitate the integration of social science information into Great Lakes fishery management based on fishery managers' opinions.

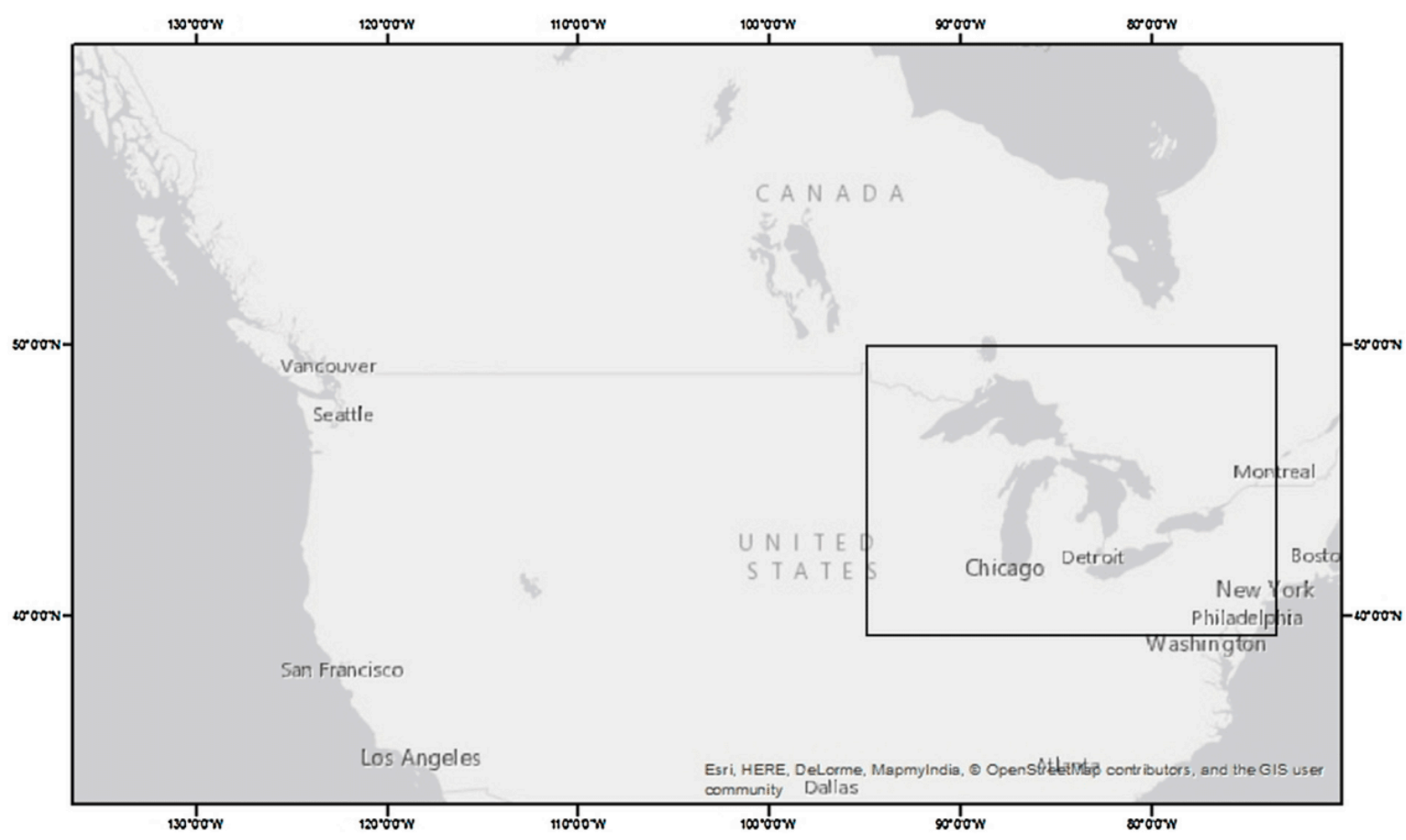

Fig. 1. Location of the Great Lakes in North America.

Fig. 1. Location of the Great Lakes in North America. 


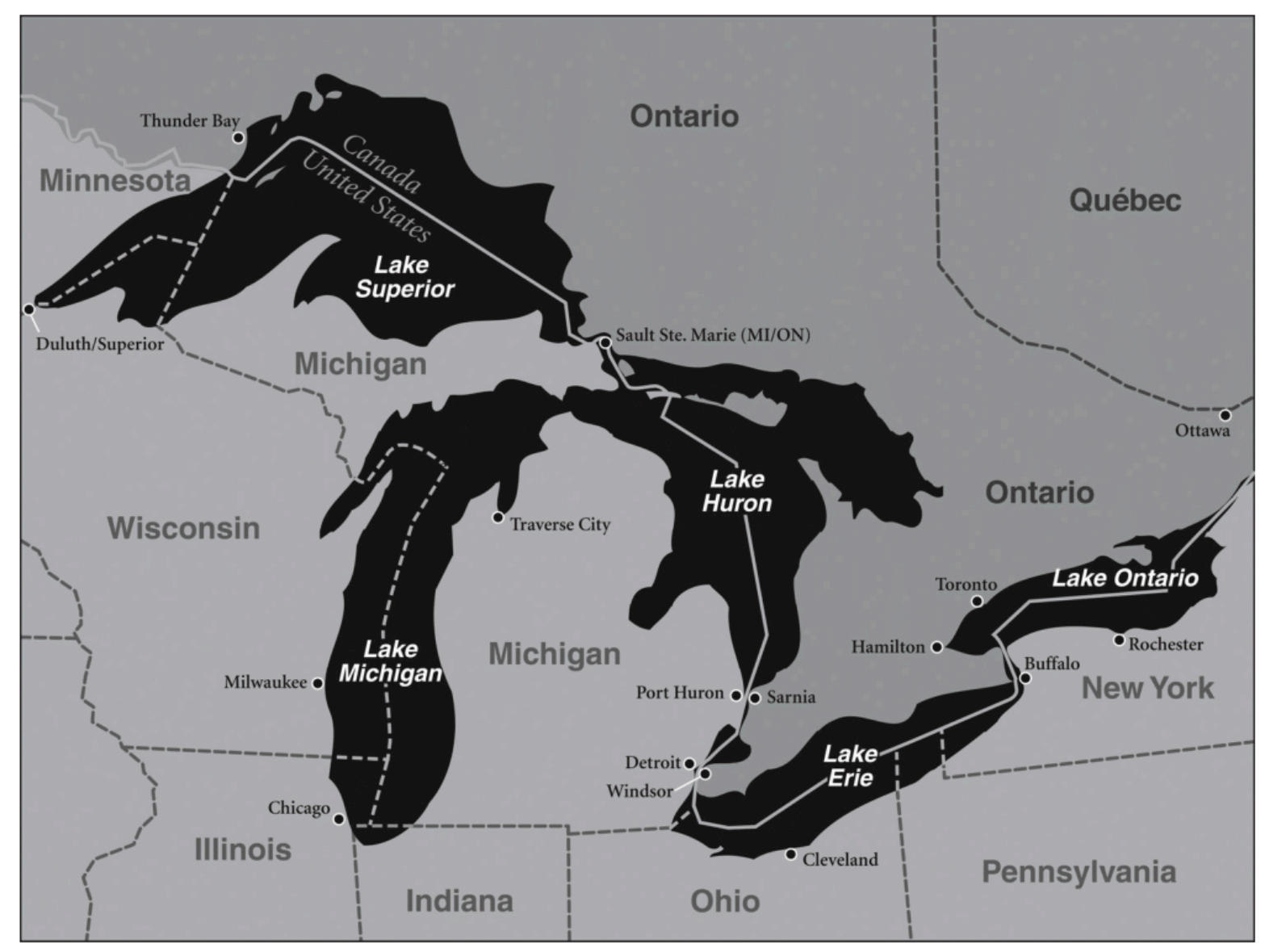

Fig. 2. Political boundaries in the Great Lakes basin.

\section{Research question and methods}

We conducted 39 face-to-face semi-structured interviews with fishery managers during the annual Great Lakes committee meetings (Table 1). The study was exploratory in nature and is not necessarily representative of all fishery managers in the basin. We interviewed fishery managers from federal, state, provincial and tribal jurisdictions in all seven US states and Ontario. As our study covers the Great Lakes fishery across the whole basin, the majority of our interviewees were involved in the management of the recreational fishery in the seven US states. 


\section{Table 1}

Interviewees job position and type of institution.

\begin{tabular}{llc}
\hline Job position & Institution & Number of interviewees \\
\hline Biologists involved in & Federal & 4 \\
management & State & 7 \\
& Provincial & 2 \\
Fishery manager & Tribal & 1 \\
& State & 17 \\
\multirow{3}{*}{ Senior fishery supervisor } & Provincial & 4 \\
& Tribal & 1 \\
& State & 2 \\
\hline
\end{tabular}

A semi-structured interview guide was used to ensure that all participants answered the same set of questions. Interviews lasted between 40 and $70 \mathrm{~min}$. Participants were assured that their comments would be treated confidentially and would not be attributed to them individually in any report or publication. The interviews centered on the following questions: (1) What are current management goals and management challenges?; (2) What kind of experience does fishery management staff have with the collection and/or use of social science information; (3) What challenges came up for the collection and/or use of social science information; (4) What suggestions do fishery management staff have to facilitate the integration of social science information into fishery management in the future?

With the consent of participants, interviews were audio recorded and transcribed. We analyzed the transcripts using computer software (Atlas.ti) designed to assist in the analysis of qualitative data. Consistent with steps pretested by Miles and Huberman (1984), interview data were coded through an ongoing process. We first engaged in pattern coding to identify broad themes, contexts, and relationships; then open coding to sort sentiments in detail, line by line; and finally cluster coding to take the detailed codes and reconstitute them into more general themes that emerged through the open coding process.

In addition to this qualitative analysis, we also calculated frequencies for each code using IBM SPSS 22.0. Frequencies of individual codes are presented in figures. Interview excerpts are included in the result section to provide evidence of the essence of a point and/or the range of perspectives. In order to keep the identity of the respondents confidential, we only identify respondents for quotations by their job position and not the institution due to the small number of interviewees from Ontario. Given the interview results are based on small, purposefully selected samples, we acknowledge issues of reliability and validity. Results based on qualitative, interpretive research depend on the subjective coding of interviews, and 
categorizations and conclusions are in turn generally influenced by the researcher's perspective. We addressed this reliability issue by transcribing the interviews verbatim and then coding them carefully and systematically, following established coding protocols. Codes were also cross-checked by two academics to increase reliability of the codes and coding process.

A major point of this research was to gauge the sentiments of the primary participants in the Great Lakes fishery management process. While the data analysis (through coding, primarily) was a subjective process, we strived to include fishery management staff in all seven Great Lakes States and Ontario. We also aimed to include fishery management staff in multiple positions (e.g. managers, biologists, senior supervisors). To increase the validity of our findings, we also conducted two focus group meetings with fishery managers and supervisors that included some people interviewed. Both groups consisted of seven participants and one additional participant that joined by telephone. Both groups lasted $90 \mathrm{~min}$. We distributed a report of our findings prior to the focus groups and used the groups to discuss our findings and to confirm whether our interpretations of the interviews were valid and useful.

\section{Findings}

The analysis revealed a variety of factors that constrain or facilitate the integration of social science information into fishery management. While these factors can be looked at in isolation, we found a number of relationships between the knowledge about social sciences principles, fishery management staff's beliefs and attitudes toward social sciences, and their intention to integrate social science information. As such, we present a conceptual model of elements that affect the use of social science information in fishery management in our study (Fig. 3).

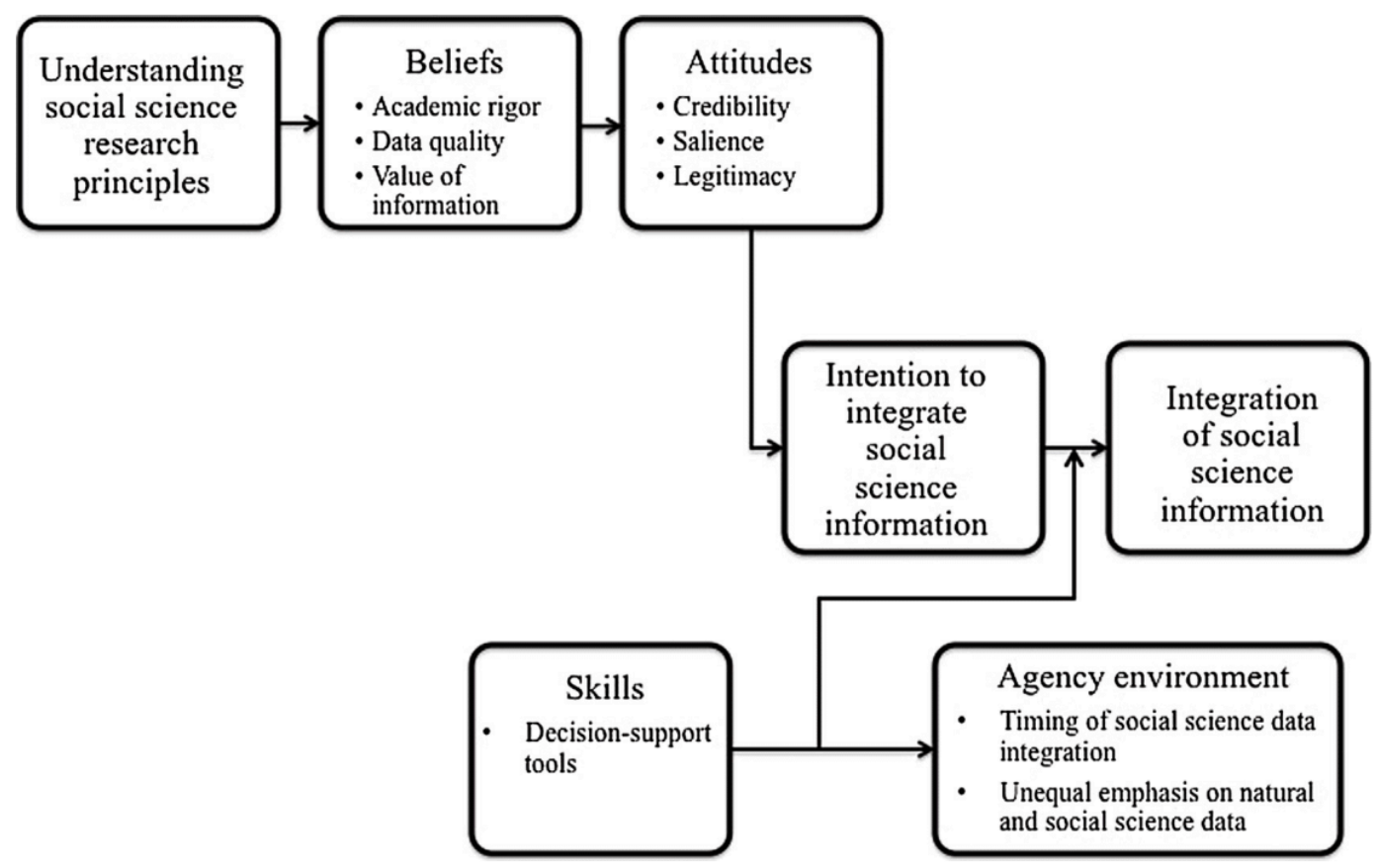

Fig. 3. Factors influencing the integration of social science information into Great Lakes fishery management. 


\section{Table 2}

Fishery management goals related to social dimensions of the fishery (\% of interviewees).

\begin{tabular}{lll}
\hline $\begin{array}{l}\text { Management } \\
\text { goal category }\end{array}$ & Management goal & \% of interviewees \\
\hline Fishing & Provide recreational fishing & 68.5 \\
& Provide economic viability for & 45.0 \\
& commercial fishery & \\
& Satisfy users & 33.7 \\
& Foster local economic development & 17.0 \\
& Maintain subsistence fishery & 12.5 \\
Non-fishing & Provide education and outreach & 25.5 \\
& Contribute to quality of life & 12.5 \\
Governance & Engage stakeholders & 16.8 \\
& Secure agency funding & 13.0 \\
& Reduce user conflicts & 8.7 \\
\hline
\end{tabular}

\section{Table 3}

Fishery management staff's perception of management challenges for social dimensions of the fishery (\% of interviewees).

\begin{tabular}{llc}
\hline $\begin{array}{l}\text { Management } \\
\text { challenge category }\end{array}$ & Management challenge & \% of interviewees \\
\hline Social & $\begin{array}{l}\text { Decline in anglers and fishermen } \\
\text { User conflicts }\end{array}$ & 52.5 \\
& User demand cannot be met by & 32.5 \\
& ecological reality & \\
& Lack of fishermen awareness and & 27.5 \\
& understanding of the fishery & \\
& Lack of agency funding from & 50.5 \\
Governance & license sales & 17.5 \\
& Conflicting legislations & 16.0 \\
& Allocation of quota & 14.5 \\
& Lack of user support for & \\
\hline
\end{tabular}




\subsection{Social dimensions context of the fishery}

We first asked fishery managers about existing management goals and management challenges to identify the role of social dimensions in the fishery. We found that fishery managers in the Great Lakes manage for a variety of management goals that fall into social dimensions of the fishery (Table 2). Fishery managers thus have to understand and manage not only for bioecological goals but also social dimensional ones.

In addition, fishery managers admitted that they struggle with a variety of management challenges that fall into the social dimensions of the fishery (Table 3). Examples included user conflicts, a decline in fishermen, especially anglers and thus a decline in license sales, and unrealistic expectations that cannot be matched by ecological realities (Table 3).

\subsection{Understanding of social sciences}

Expertise in social sciences, however, seems to be underdeveloped in Great Lakes fishery management agencies. We found that staff within fishery management agencies consists exclusively of natural scientists. Fishery managers thus do not have expertise or training to collect and understand social science information. Respondents in our study were aware of this fact. They pointed out that they are narrowly educated in ecology or biology and have little to no expertise in social science methods and the application of such data to fishery management.

I think one of the biggest challenges that l've seen so far is internal staff that went to school 20 years ago (and) didn't have any social science classes.

That's probably the biggest challenge that I see right now (Fishery manager).

Subsequently, previous social science data collection within fishery management agencies has been collected by staff who was untrained in social science research principles. Respondents mentioned basic data on user patterns, recreational and commercial fishermen expectations and concerns, fishermen knowledge and understanding about the fishery, and recreational and commercial fishermen's views on current management performance. Most of the data collected internally, however, has been collected unsystematically and ad-hoc. Fishery management staff in our study, for example, equated hearing of user opinions through informal comments or by "sitting face to face in a bar" (Biologist), informal talks, phone calls, and letters to managers as the collection of social science information. Harvest allocation expectations were discussed in direct negotiations among tribal fishers, non-tribal commercial fishers, and anglers. At the same time, interviewees themselves pointed out their lack of collecting and understanding social science information:

We just don't have a lot of social science competency, we don't understand it. We don't understand the questions we need to ask and we don't understand the methodology to ask the questions to get at the answer (Fishery manager).

Building on this recognition, fishery managers pointed out the need to increase social science expertise in fishery management agencies and suggested "you either hire the staff internally to have social scientists on staff, or you have them available at some place (. . .) where we can 
contract with them and get it done." (Fishery manager) Another staff member made a similar point for the interpretation of available social science information:

We need the social science people to teach us how to interpret the results when we get them (so) that fisheries managers understand exactly what the information means. (Biologist)

These statements reflect the lack of social science training among staff and the lack of basic social science research principles such as sampling schemes or research design. To make up for this lack of expertise, fishery managers suggested to hire staff trained in both a social and natural science background e.g. a fishery ecologist with an additional degree or training in a social science discipline or vice versa.

\subsection{Beliefs about social science information}

The majority of fishery managers believed that social sciences lack academic rigor and applicability. These beliefs seemed to be grounded, at least in part, in the lack of understanding of social science principles and methods. Fishery management staff mentioned that if "[/]you don't understand how the information was collected, you don't necessarily see the value." (Biologist) This comment highlighted the link between an understanding of social science methods and the perceived value and importance of such information for fishery management: "fishery biologists and scientists (who are) not schooled in social sciences may look down at it." (Fishery supervisor)

The degree of training and thus familiarity with distinct methodological approaches also influenced beliefs about the nature of different kinds of social science information. As natural scientists are familiar with quantitative methods, they had more positive beliefs about the quality of quantitative social science information, and felt that that quantitative data is "more scientific" (Biologist) and "easier to defend." (Tribal manger) They acknowledged that they preferred quantitative social science information because they are familiar with such data:

We tend to lean towards quantitative for obvious reasons; it is what we do and we try to base things on in [natural] science. I think it is far better to have something that is controlled, repeatable and quantifiable rather than going to a meeting and recording some opinions on a flip chart and summarizing what people said. (Fishery manager)

Interviewees also emphasized that "social science information has to be collected using the same principles as natural science data." (Biologist) Fishery management staff did not seem open to scientific information that is not based on empirical observations that are based on a deductive, hypothesis testing approaches.[I]

This point was confirmed in the perception of qualitative information. Very few fishery managers in our study have collected qualitative information. This unfamiliarity with qualitative data diminished the perceived value of qualitative information. 
I am not sure how accurate (qualitative data) would be because it is an oral history and there is no real reference to timing, at least in our sense, like decades or century or millennia. (Fishery supervisor)

Qualitative information that has been collected in the past mainly derived from interactions with First Nations with regard to ecological knowledge. In these cases, the degree of familiarity with qualitative information among fishery managers seemed to increase the perceived value of qualitative data to some extent:

Some management decisions are very easily answered by a quantitative decision ... .it's nice to have yes or no, black or white, one or two, or one or zero, and those are easy to calculate[|]. ... But there are many shades of grey, so you need that additional (qualitative) information." (Biologist)

Quantitative is something that people are used to seeing as science but the qualitative piece is what makes the story for the quantitative piece. You need both to tell the story otherwise it is just numbers. And the qualitative piece is often the hook that gets you into the numbers to get you to look at them more deeply [I.] (Fishery supervisor)

Overall, these comments highlighted that an understanding of social science principles seemed to influence beliefs about academic rigor, quality of data, and the perceived value of such information to fishery management.[l]

\subsection{Attitudes toward social science information}

Negative beliefs about social science information, such as described above, in turn seemed to produce almost hostile attitudes toward social science that subsequently affected the intention of integrating such information into decision-making processes.

\subsubsection{Credibility}

A perceived lack of academic rigor in social science seemed to evoke a "fundamental distrust of socio-economists" (Fishery supervisor) and the feeling that "you can tailor the socioeconomic data to reach the conclusion that you wish" (Fishery supervisor). At the same time, respondents acknowledged that this distrust might be based on insufficient understanding and familiarity with social science information as they pointed out that "perhaps it is a reflection of that fact that we don't fully understand socioeconomic data." (Fishery manager)

\subsubsection{Salience}

Social science information was also seen as less salient to fishery management compared to natural science data. Collected social science information thus often ends up on the shelf and is not applied in the decision-making process: 
It is nice to have, but (...) you don't really need it... It's always in the back

of your mind a little bit but I wouldn't say it's at the forefront of the decisions we make around fisheries management." (Biologist)

There is a lot research out there that never gets used. It was good research for the sake of research but it didn't help management." (Fishery Manager)

This point highlights that social science information, even if it is collected rigorously, might not necessarily be applied if fishery management staff do not realize the salience of the collected information due to a lack of knowledge of how to interpret social science information.

\subsubsection{Legitimacy}

Fishery managers also felt that social science information needs to be collected and peer reviewed by trained social scientists and fishery professionals "with a collective experience of so and so many years." (Fishery manager) In addition, fishery managers mentioned that social science information "needs to be collected by individuals or researchers who are perceived as neutral on the topic" (Fishery manager). This point was cited to social science information to avoid any potential bias.

\subsection{Factors affecting the actual integration of social science information}

While beliefs and attitudes of fishery management staff underpinned their intention to integrate social science information into fishery management, we also found multiple factors that affect the actual integration of social science information.

Fishery managers, for example, seem to lack decision-making skills to integrate social science information. They pointed out that "in many cases [managers] don't know how to use the data and how to incorporate that into a management decision." (Senior Supervisor) Interviewees described a lack of decision-making tools that would facilitate integration of social science information: "we don't have a rigorous decision model that has a place for social science and it's unfortunate. It's an area that we're deficient in." (Fishery manager) The few managers that attempted to integrate natural and social science information in decision-making processes in past, mentioned that they struggled with how to weight different types of data in the decisionmaking process:

So if the social science says you can probably go about 5 or 10 percent higher and provide a really good solid economic return here, how do you weigh that against the biological side? (Fishery manager)

Decision-making tools currently used in fishery management agencies thus do not allow the integration of social science information, and thus to integrate natural and social science information.

It also became clear during the interviews that the institutional environment within fishery management agencies is affecting the integration of social science information. Fishery management agencies in the Great Lakes still put more emphasis on natural sciences compared 
to social sciences. A comment signified that a cut in funding first leads first to a cut in the collection of social science information and an emphasis to rely solely on biological "core" information:

Under tough economic budget times, we tend to get back to just core data that we need, typically the biological data[I]. We know that social data is important, and we try to get there at some point, but I feel like every time we try to take a step in that direction we take a step back when budgets become bad. (Fishery manager)

Other comments referred to the timing of the integration of social science information in the decision-making process within agencies. Respondents felt that social science often came in too late for a meaningful connection between ecological and social information. One manager said that usually biologists "work out the best biological option (and) then the social comes in at the end out of context." (Fishery manager) Some managers reflected that social science needs to be brought into the discussion right from the start and not as "an appendage at the end" (Fishery manager) to give it "sincere attention and importance" (Fishery manager) within fishery management agencies.

\section{Discussion}

An understanding of ecological and social dimensions and the integration of natural and social science information has proven critical to enable management and decision-making of fisheries (Hunt et al., 2013; Coll et al., 2013; Haapasaari et al., 2012), especially given the fact that management itself often focuses on to managing human behavior (Mascia, 2003; Fulton et al., 2011). Nevertheless, decision-making processes in management agencies are, in many cases, still primarily based on ecological and biological information, which also seems to be the case in our Great Lakes-based research. This lack of integration of social science information within fisheries management has been pointed out in previous studies (e.g. Hunt et al., 2013; Fulton and Adelman, 2003). Our research expands and refines these findings and makes a distinction among factors that influence the intention to use social science information and the actual integration of social science information into fishery management and decision-making.

A lack of expertise in social science theories and methods, in particular, seems to influence the intention to integrate social science information. This finding further supports insights from previous studies that found that a lack of awareness of social science theory and a lack of social science staff in fish and wildlife agencies limits the integration of social sciences into fisheries (Sharp and Lach, 2003; Ditton, 1996; Wilde et al., 1996; Hunt et al., 2013; Fulton et al., 2011). In our case, a lack of social science training and expertise lead to negative beliefs and attitudes toward social science information and subsequently a low intention to make use of social science information, which is a first step to integrate such information.

Most state and provincial fish and wildlife agencies in our study did not seem to realize the importance of social science expertise, even though they seem interested in accounting for social issues in their management of fishery systems. Previous studies found that hiring social 
scientists can provide in-house expertise that can contribute to design, implementation, and analysis of high priority social science research (Cook et al., 2013). This reduces the likelihood that key decisions are based on conventional natural science disciplinary outcomes alone (e.g. Liu et al., 2007; Lele and Kurien, 2011; Janssen and Goldsworthy, 1996). Federal agencies in the US, such as NOAA, seem to recognize this point and have started to hire social scientists and even created fishery programs that focus on social and economic considerations of fisheries in different geographical regions in the US (e.g. NOAA, 2014a,b). These programs not only cover profiles of fisheries but also examine wider impacts of fisheries on local communities and regional economies. Our study finds that hiring social science staff would be equally important in state and provincial fish and wildlife agencies. Right now, fishery managers lack experience in social sciences to provide high quality social science information and lack the ability to use such information in management and decision-making processes.

The lack of social science expertise in fishery management agencies seemed to be at the core of negative beliefs and attitudes toward social science. Fishery managers in our study that have collected social science information in the past did not follow social science research designs. The neglect of social science principles most likely contributed to the beliefs that social science information is not rigorous, the collected data of low quality, of limited value to fishery management. Unfamiliarity with principles and assumptions of a certain discipline indeed typically compromises the integrity and validity of the research design (Moon and Blackman, 2014), which also seems to be the case in our study. Differences in underlying epistemologies in natural and social sciences and a lack of their understanding thus seems to play an important role for the integration of social science information into areas that were preliminary dominated by natural sciences in the past such as fisheries or ecosystem based management and conservation (Sievanen et al., 2012; Moon and Blackman, 2014). Fishery management staff who make decisions that are based on or that affect people, need to understand the basic principles of social sciences, or at least have ready access to those who do.

We found that the lack of expertise in social science methods and negative beliefs about social science information undermined the perceived credibility and salience of social science data that are both are critical to translate any science into action (Cash et al., 2003). The fact that fishery management staff trained in ecology and biology collected social science information without methodological training may contribute to the perception that social sciences lack academic rigor. If information that is collected informally or unstructured is perceived as "social science", it does not seem surprising that academic rigor of social sciences might be perceived as low or negligible and such information subsequently perceived as not credible and of low value to fishery management. This point highlights that scientific information needs to be collected by people trained in the appropriate discipline. While this seems to be the norm for natural sciences within fishery management agencies, it does not seem to apply to social sciences yet.

Fishery management staff also failed to realize the salience of collected information, as they did not know how to interpret the information and how it could be used in fishery management. Fishery management staff subsequently failed to understand the potential contribution of 
social science information to fishery management, which has been noted in other studies (Wilde et al., 1996; Sharp and Lach, 2003; Ditton, 1996; Arlinghaus and Cowx, 2008). This finding confirms that a lack of understanding of principles and assumptions of a discipline most likely limits or even distorts the interpretation of research findings (Sievanen et al., 2012).

In our case, the lack of expertise in social sciences among fishery management staff means that even if there will be a greater supply of social science information, such information might not increase the intention to integrate social science information. If management staff does not understand research outcomes, and how to apply them to fishery management, the relevance of social science information will not be apparent and such information will not be applied in the Great Lakes basin.

At the same time, we identified multiple factors that challenge the actual integration of social science information into fishery decision-making processes. This finding demonstrates that even if fishery manager perceive social science information to be salient, legitimate, and credible, the information might still not be integrated into decision-making processes. A lack of decision-making tools that allow integrating and weighting natural and social science information, for example, was one of the main factors that challenge the actual integration. In addition to social science expertise, fishery management agencies thus seem to lack expertise in decision-making tools that allow integrating natural and social science information. The challenge to integrate multiple kinds of data is not uncommon in fisheries management (McClanahan et al., 2009; De Young et al., 2008) but undermines the opportunity to base decisions on defensible ecological and social information. Examples of decision-making tools that could be used in fisheries include interdisciplinary modeling (Johnston et al., 2010, 2013; Fenichel et al., 2013), multi-criteria decision analysis that are common for the management of a variety of natural resources (Beard et al., 2011; Huang et al., 2011), the integration of qualitative information via spatial tools such as GIS systems (e.g. Close and Hall, 2006; Turner et al., 2015), or trade-off analysis (Riley and Gregory, 2012) that illustrate how outcomes of a policy or program will change if one or more factors are increased (e.g. availability of target fish) and subsequently other factors decrease (e.g. amount of fishing and license sales). Knowledge among practitioners and decision-makers about these and related tools that facilitate the integration of information from multiple disciplines needs to be expanded. Ideally, these tools might also foster more interdisciplinary thinking, which is already apparent in academic research disciplines such as agro-ecology or political ecology (Lele and Norgaard, 2005) but is underdeveloped in policy and decision-making processes within fishery management agencies.

The institutional environment also plays a significant role for the integration of social science information into decision-making processes, which is not uncommon (Lele and Norgaard, 2005; Symes and Phillipson, 2009). Participants in our study pointed out the importance of timing in the integration of natural and social science information. Social science information often comes in after preliminary decisions have been made based on natural science information. In order to allow for informed decision-making, both kinds of information should be "on the 
table" right from the start and be combined in a transparent manner to demonstrate how the final decision is being made.

The greater emphasis on natural science information within agencies in our study appears to evoke a feeling that social science information is not "core" to fishery management and plays a minor role for decision-making processes, echoing findings by Hunt et al. (2013) and Arlinghaus et al. (2008) about the perceived lack of importance of social science research findings. If agencies are serious about the integration of ecological and social information into fishery management, they should follow up this intention with a more equal emphasis on natural and social science information. Otherwise social science information might still be seen as "inferior" to natural science information and not be included in policy and decision-making processes. This point is critical since fishery management aims to influence human behavior and basing decision-making solely on ecological and biological information seems is neither logical, nor likely to result in effective management.

\section{References}

Arlinghaus, R., 2006. Overcoming human obstacles to conservation of recreational fishery resources, with emphasis on Central Europe. Environ. Conserv. 33 (1), 46-59, http://dx.doi.org/10.1017/S0376892906002700.

Arlinghaus, R., Cooke, S.J., Potts, W., 2013. Towards resilient recreational fisheries on a global scale through improved understanding of fish and fisher behaviour. Fish. Manage. Ecol. 20 (23), 91-98, http://dx.doi.org/10.1111/fme.12027.

Arlinghaus, R., Cowx, I.G., 2008. Meaning and relevance of the ecosystem approach to recreational fisheries management: emphasis on the importance of the human dimension. In: Global Challenges in Recreational Fisheries. Blackwell Publishing Ltd., pp. 56-74.

Arlinghaus, R., Brett, M.J., Christian, W., 2008. The past, present and future role of limnology in freshwater fisheries science. Int. Rev. Hydrobiol. 93 (4-5), 541-549, http://dx.doi.org/10.1002/iroh.200711047.

Bain, M.B., Cornwell, E.R., Hope, K.M., Eckerlin, G.E., Casey, R.N., Groocock, G.H., Getchell, R.G., Bowser, P.R., Winton, J.R., Batts, W.N., Cangelosi, A., Casey, J.W., 2010. Distribution of an invasive aquatic pathogen (viral hemorrhagic septicemia virus) in the Great Lakes and its relationship to shipping. PLoS ONE 5 (4), e10156, http://dx.doi.org/10.1371/journal.pone.0010156.

Beard, D.T., Arlinghaus, R., Cooke, S.J., Mclntyre, P.B., De Silva, S., Bartley, D., Cowx., I.G., 2011. Ecosystem approach to inland fisheries: research needs and implementation strategies. Biol. Lett. 7 (4), 481-483, http://dx.doi.org/10.1098/rsbl.2011.0046. 
Bishop, R.C., Boyle, K.J., Welsh, M.P., 1987. Toward total economic valuation of Great Lakes fishery resources. Trans. Am. Fish. Soc. 116 (3), 339-345, http://dx.doi.org/10.1577/15488659(1987)116<339:ttevog>2.0.c0;2.

Bishop, R.C., Milliman, S.R., Boyle, K.J., Johnson, B.L., 1990. Benefit-cost analysis of fishery rehabilitation projects: a Great Lakes case study. Ocean Coast. Manage. 13 (3-4), 253-274, http://dx.doi.org/10.1016/0951-8312(90)90005-3.

Breffle, W.S., Muralidharan, D., Donovan, R.P., Liu, F., Mukherjee, A., Jin, Y., 2013. Socioeconomic evaluation of the impact of natural resource stressors on human-use services in the Great Lakes environment: a Lake Michigan case study. Resourc. Policy 38 (2), 152-161, http://dx.doi.org/10.1016/j.resourpol.2012.10.004.

Bunnefeld, N., Hoshino, E., Milner-Gulland, E.J., 2011. Management strategy evaluation: a powerful tool for conservation? Trends Ecol. Evol. 26 (9), 441-447, http://dx.doi.org/10.1016/j.tree.2011.05.003.

Cash, D.W., Clark, W.C., Alcock, F., Dickson, N.M., Eckley, N., Guston, D.H., Jäger, J., Mitchell, R.B., 2003. Knowledge systems for sustainable development. Proc. Natl. Acad. Sci. 100 (14), 8086-8091, http://dx.doi.org/10.1073/pnas.1231332100.

Cline, T.J., Bennington, V., Kitchell, J.F., 2013. Climate change expands the spatial extent and duration of preferred thermal habitat for Lake Superior fishes. PLOS ONE 8 (4), e62279, http://dx.doi.org/10.1371/journal.pone.0062279.

Cline, T.J., Kitchell, J.F., Bennington, V., McKinley, G.A., Moody, E.K., Weidel, B.C., 2014. Climate impacts on landlocked sea lamprey: implications for host-parasite interactions and invasive species management. Ecosphere 5 (6), 68, http://dx.doi.org/10.1890/ES14-00059.1.

Close, C.H., Hall, B.G., 2006. A GIS-based protocol for the collection and use of local knowledge in fisheries management planning. J. Environ. Manage. 78 (4), 341-352, http://dx.doi.org/10.1016/j.jenvman.2005.04.027.

Coll, M., Cury, P., Azzurro, E., Bariche, M., Bayadas, G., Bellido, J.M., Chaboud, C., Claudet, J., ElSayed, A.-F., Gascuel, D., Knittweis, L., Pipitone, C., Samuel-Rhoads, Y., Taleb, S., Tudela, S., Valls, A., 2013. The scientific strategy needed to promote a regional ecosystem-based approach to fisheries in the Mediterranean and Black Seas. Rev. Fish Biol. Fish. 23 (4), 415-434, http://dx.doi.org/10.1007/s11160-013-9305-y.

Connelly, N.A., Brown, T.L., Knuth, B.A., Wedge, L., 1999. Changes in the utilization of New York's Great Lakes recreational fisheries. J. Great Lakes Res. 25 (2), 347-354, http://dx.doi.org/10.1016/s0380-1330(99)70743-4. 
Connelly, N., Brown, T., 2010. Assessing the economic importance of recreational fishing for communities along Lake Ontario. Tour. Mar. Environ. 6 (2-3), 63-71.

Cook, C.N., Mascia, M.B., Schwartz, M.W., Possingham, H.P., Fuller, R.A., 2013. Achieving conservation science that bridges the knowledge-action boundary. Conserv. Biol. 27 (4), 669678, http://dx.doi.org/10.1111/cobi.12050.

De Young, C., Charles, A., Hjort, A., 2008. Human dimensions of the ecosystem approach to fisheries: an overview of context, concepts, tools and methods, FAO Fisheries Technical Paper.

Decker, D.J., Brown, T.L., Siemer, W.F., 2001. Human Dimensions of Wildlife Management in North America. The Wildlife Society, Bethesda, MA.

Decker, D.J., Shawn, J.R., Siemer, W.F., 2012. Human Dimensions of Wildlife Management, 2nd ed. The John Hopkins University Press, Baltimore.

Ditton, R.B., 1996. Human dimensions in fisheries. In: Ewert, A.W. (Ed.), Natural Resource Management: The Human Dimension, Westview Press, Oxford, pp. 74-90.

Eigenbrode, S.D., Michael O'rourke, J.D., Wulfhorst, D.M., Althoff, C.S., Goldberg, K.M., Morse, W., Nielsen-Pincus, M., Stephens, J., Winowiecki, L., Bosque-Pérez, N.A., 2007. Employing philosophical dialogue in collaborative science. BioScience 57 (1), 55-64, http://dx.doi.org/10.1641/b570109.

Evely, A.C., Fazey, I., Pinard, M., Lambin, X., 2008. The influence of philosophical perspectives in integrative research: a conservation case study in the Cairngorms National Park. Ecol. Soc. 13 (2), 52.

Fazey, I., Fazey, J.A., Salisbury, J.G., Lindenmayer, D.B., Dovers, S., 2006. The nature and role of experiential knowledge for environmental conservation. Environ. Conserv. 33, 1-10.

Fenichel, E.P., Abbott, J.K., Huang, B., 2013. Modelling angler behaviour as a part of the management system: synthesizing a multi-disciplinary literature. Fish Fish. 14 (2), 137-157, http://dx.doi.org/10.1111/j.1467-2979.2012.00456.x.

Fulton, E.A., Adelman, I.R., 2003. Social science (the human dimension) in fisheries. Fisheries 28 (11), 4.

Fulton, E.A., Smith, A.D.M., David, C.S., van Putten, I.E., 2011. Human behaviour: the key source of uncertainty in fisheries management. Fish Fish. 12 (1), 2-17, http://dx.doi.org/10.1111/j.1467-2979.2010.00371.x.

Gaden, M., Goddard, C.I., Read, J., 2012. A history of multi-jurisdictional management of the shared Great Lakes fishery: transcending conflict and diffuse political authority. In: Taylor, 
W.W., Lynch, A.J., Leonard, N.J. (Eds.), Great Lakes Fishery Management and Policy. Michigan University Press, East Lansing.

Haapasaari, P., Kulmala, S., Kuikka, S., 2012. Growing into interdisciplinarity: how to converge biology, economics, and social science in fisheries research? Ecol. Soc. 17 (1), 135-146.

Heberlein, T.A., 1988. Improving interdisciplinary research: integrating the social and natural sciences. Soc. Nat. Resourc. 1 (1), 5-16, http://dx.doi.org/ 10.1080/08941928809380634.

Holling, C.S., 1998. Two cultures of ecology. Conserv. Ecol. 2 (2), 4.

Huang, I.B., Jeffrey, K., Igor, L., 2011. Multi-criteria decision analysis in environmental sciences: ten years of applications and trends. Sci. Total Environ. 409 (19), 3578-3594, http://dx.doi.org/10.1016/j.scitotenv.2011.06.022.

Hunt, L.M., Sutton, S.G., Arlinghaus, R., 2013. Illustrating the critical role of human dimensions research for understanding and managing recreational fisheries within a social-ecological system framework. Fish. Manage. Ecol. 20 (2-3), 111-124, http://dx.doi.org/10.1111/j.13652400.2012.00870.x.

Janssen, W., Goldsworthy, P., 1996. Multidisciplinary research for natural resource management: conceptual and practical implications. Agric. Syst. 51 (3), 259-279, http://dx.doi.org/10.1016/0308-521X(95)00046-8.

Johnston, F.D., Arlinghaus, R., Dieckmann, U., 2010. Diversity and complexity of angler behaviour drive socially optimal input and output regulations in a bioeconomic recreational fisheries model. Can. J. Fish. Aquat. Sci. 67 (9), 1507-1531, http://dx.doi.org/10.1139/F10-046.

Johnston, F.D., Arlinghaus, R., Dieckmann, U., 2013. Fish life history, angler behavior and optimal management of recreational fisheries. Fish Fish. 14 (4), 554-579, http://dx.doi.org/10.1111/j.1467-2979.2012.00487.x.

Kelly, N.E., Wantola, K., Weisz, E., Yan, N.D., 2013. Recreational boats as a vector of secondary spread for aquatic invasive species and native crustacean zooplankton. Biol. Invasions 15 (3), 509-519, http://dx.doi.org/10.1007/s10530-012-0303-0.

Kilian, J.V., Klauda, R.J., Widman, S., Kashiwagi, M., Bourquin, R., Weglein, S., Schuster, J., 2012. An assessment of a bait industry and angler behavior as a vector of invasive species. Biol. Invasions 14 (7), 1469-1481, http://dx.doi.org/10.1007/s10530-012-0173-5.

Lele, S., Kurien, A., 2011. Interdisciplinary analysis of the environment: insights from tropical forest research. Environ. Conserv. 38 (2), 211-233, http://dx.doi.org/10.1017/S037689291100018X. 
Lele, S., Norgaard, R.B., 2005. Practicing interdisciplinarity. BioScience 55 (11), 967-975, http://dx.doi.org/10.1641/0006-3568(2005)055[0967:PI]2.0.CO;2. Liu, J., Dietz, T., Carpenter, S.R., Alberti, M., Folke, C., Moran, E., Pell, A.N., Deadman, P., Kratz, T., Lubchenco, J., Ostrom, E., Ouyang, Z., Provencher, W., Redman, C.L., Schneider, S.H., Taylor, W.W., 2007. Complexity of coupled human and natural systems. Science 317 (5844), 1513-1516, http://dx.doi.org/10.1126/science.1144004.

Mahon, R., McConney, P., Roy, R.N., 2008. Governing fisheries as complex adaptive systems. Mar. Policy 32 (1), 104-112. Mascia, M.B., 2003. The human dimension of coral reef marine protected areas: recent social science research and its policy implications. Conserv. Biol. 17, 630-632.

McClanahan, T., Castilla, J., White, A., Defeo, O., 2009. Healing small-scale fisheries by facilitating complex socio-ecological systems. Rev. Fish Biol. Fish. 19 (1), 33-47, http://dx.doi.org/10.1007/s11160-008-9088-8.

Miles, M.B., Huberman, A.M., 1984. Qualitative Data Analysis. Sage, Newbury Park.

Milliman, S.R., Johnson, B.L., Bishop, R.C., Boyle, K.J., 1992. The bioeconomics of resource rehabilitation: a commercial-sport analysis for a Great Lakes fishery. Land Econ. 68 (2), 191 210, http://dx.doi.org/10.2307/3146774.

Möllmann, C., Lindegren, M., Blenckner, T., Bergström, L., Casini, M., Diekmann, R., Flinkman, J., Müller-Karulis, B., Neuenfeldt, S., Schmidt, J.O., Tomczak, M., Voss, R., Gårdmark, A., 2013. Implementing ecosystem-based fisheries management: from single-species to integrated ecosystem assessment and advice for Baltic Sea fish stocks. ICES J. Mar. Sci.: J. Conseil, http://dx.doi.org/10.1093/icesjms/fst123.

Moon, K., Blackman, D., 2014. A guide to understanding social science research for natural scientists. Conserv. Biol., http://dx.doi.org/10.1111/cobi.12326. NOAA, 2014a. Economic and Social Science Research. Northwest Fisheries Science Center, Available from: http://www.nwfsc.noaa.gov/research/divisions/fram/economic/index.cfm (cited 07.01.14).

NOAA, 2014b. Social Science Branch. Southeast Regional Office, Available from:

http://sero.nmfs.noaa.gov/sustainable fisheries/social/index.html (cited 07.01.14).

Ostrom, E., 1999. Coping with tragedies of the commons. Annu. Rev. Polit. Sci. 2, 493-535.

Pejchar, L., Mooney, H.A., 2009. Invasive species, ecosystem services and human well-being. Trends Ecol. Evol. 24 (9), 497-504.

Riley, S.J., Gregory, R.S., 2012. Decision making in wildlife management. In: Decker, D.J., Riley, S.J., Siemer, W.F. (Eds.), Human Dimensions of Wildlife Management. The Johns Hopkins University Press, Baltimore, MA. 
Rothlisberger, J.D., Lodge, D.M., Cooke, R.M., Finnoff, D.C., 2010. Future declines of the binational Laurentian Great Lakes fisheries: the importance of environmental and cultural change. Front. Ecol. Environ. 8 (5), 239-244.

Roy, E.D., Martin, J.F., Irwin, E.G., Conroy, J.D., Culver, D.A., 2010. Social-ecological stability: the effects of invasive species and ecosystem restoration on nutrient management compromise in Lake Erie. Ecol. Soc. 15 (1), 20.

Sharp, S.B., Lach, D., 2003. Integrating social values into fisheries management. Fisheries 28 (4), 10-15, http://dx.doi.org/10.1577/1548agement.8446(2003)28[10:ISVIFM2.0.CO;2].

Sievanen, L., Campbell, L.M., Leslie, H.M., 2012. Challenges to interdisciplinary research in ecosystem-based management (Retos para la Investigación Interdisciplinaria en el Manejo Basado en Ecosistemas). Conserv. Biol. 26 (2), 315-323, http://dx.doi.org/10.1111/j.15231739.2011.01808.x.

Symes, D., Hoefnagel, E., 2010. Fisheries policy, research and the social sciences in Europe: challenges for the 21st century. Mar. Policy 34 (2), 268-275.

Symes, D., Phillipson, J., 2009. Whatever became of social objectives in fisheries policy? Fish. Res. 95 (1), 1-5.

Turner, R.A., Polunin, N.V.C., Stead, S.M., 2015. Mapping inshore fisheries: comparing observed and perceived distributions of pot fishing activity in Northumberland. Mar. Policy 51 (0), 173 181, http://dx.doi.org/10.1016/j.marpol.2014.08.005.

Urquhart, J., Acott, T., Reed, M., Courtney, P., 2011. Setting an agenda for social science research in fisheries policy in Northern Europe. Fish. Res. 108, 240-247.

Wilde, G.R., Ditton, R.B., Grimes, S.R., Riechers, R.K., 1996. Status of human dimensions surveys sponsored by state and provincial fisheries management agencies in North America. Fisheries 21 (11), 12-17, http://dx.doi.org/10.1577/1548-8446(1996)021<0012:SOHDSS>2.0.CO;2. 